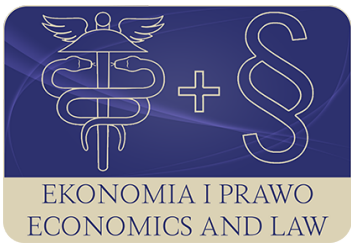

EKONOMIA I PRAWO. ECONOMICS AND LAW

Volume 18, Issue 3, September 2019

p-ISSN 1898-2255, e-ISSN 2392-1625

www.economicsandlaw.pl

ORIGINAL ARTICLE

received 27.06.2018; revised 09.08.2019; accepted 30.09.2019

Citation: Szczepaniak, M., \& Szulc-Obłoza, A. (2019). Labour market institutions and income inequalities across the European Union. Ekonomia i Prawo. Economics and Law, 18(3): 365-377.

doi:10.12775/EiP.2019.025.

\title{
Labour market institutions and income inequalities across the European Union
}

\author{
MAEGORZATA SZCZEPANIAK \\ corresponding author \\ Nicolaus Copernicus University in Torun, Faculty of Economic Sciences and Management, \\ Department of Economics, ul. Gagarina 13a, 87-100 Toruń, Poland \\ ๑m.szczepaniak@umk.pl \\ (D) orcid.org/0000-0001-6007-8430
}

AGNIESZKA SZULC-OBEOZA

Nicolaus Copernicus University in Torun, Faculty of Economic Sciences and Management, Department of Human Resource Management, Poland

๑aszulc@umk.pl

orcid.org/0000-0002-7281-6813

\begin{abstract}
Motivation: Labour market institutions are currently considered as the basic condition for high level of economic development. Decreasing income inequalities on contrary are among the main objectives of macroeconomic policy in the European Union (Europe 2020 Strategy), because unequal distribution may result in lower growth and development

rates. The research done in the article is consisted with the institutional theory (D.C.

North's interpretation).

Aim: The main aim of the article is to analyse the relations between labour market institutions and income inequalities. There is also an attempt to answer the question if rigid labour market institutions reduce income inequality in European countries. This article provides a taxonomic analysis of labour market institutions in the EU countries. Data from Eurostat, World Bank, Fraser Institute, OECD are used. The article covers selected years: 2010 and 2016.

Results: The countries were grouped according to the level of labour market institutions and in regard to income inequalities. The differences between the members of the groups were analysed between 2010 and 2016. Article ends with conclusions connected with
\end{abstract}


rules shaping decisions on the labour market as well as relations between inequalities and institutions.

Keywords: income inequalities; labour market; institutions

JEL: B52; D63; E02; J88; O43

\section{Introduction}

European Union's policy focuses on an inclusive and sustainable growth of human development. The aim of these strategies is to reduce the income inequalities which results in lower standard of living. Labour market institutions are supposed to be the fundamental factors for decreasing the inequalities and improving the social inclusion (European Commission, 2010; United Nations, 2015).

Labour institutions affect how the labour market works because players respond to an existing set of rules (Berg \& Kucera, 2008; Scott, 2014). In fact not one rule but varying combinations of institutions determine actors situation (Scott, 2014). Rules used by participants to order their relationships on the labour market are usually identified with policy interventions of supply as well as demand side of the labour market (Holmlund, 2014). The most popular definition of institutions is from D.C. North (2002), who defines institutions as constraints imposed on human interaction and therefore shape the way in which society and the economy work. D.C. North $(1990$, pp. 3, 6) compare institutions to the rules of the game. Institutions consist of formal rules (written rules) informal constraints (norms of behaviour, conventions, codes of conduct) and their enforcement (North, 1990; 1993). In the article only formal rules are analysed from employee's perspective. According to the point presented by D. Acemoglu and J. Robinson (2012), institutions may be divided into inclusive and extractive rules. Inclusive rules give people freedom, they encourage economic activity, productivity growth and economic prosperity. However extractive rules relocate incomes and wealth from one subset of society to benefit a different group. Institutions may be also analysed by flexible or rigid criteria. Rigid institutions precisely define what is permitted and therefore do not leave the space to flexible reactions of actors on the labour market.

\section{Relations between inequalities and labour market institution: literature review}

In the vast majority of literature, there is an opinion that income inequality can be reduced by the institutions - the laws, policies and practices - that govern the society, its economy and, in particular, its labour market. Erosion of such institutions that support the creation of quality jobs with decent wages and good working conditions has contributed to rising inequalities in many countries worldwide, jeopardizing individual as well as societal wellbeing (Acemoglu \& 
Robinson, 2013, pp. 173-92). The reforms undertaken under the Washington Consensus such as reduction of employment protection, although their role was to increase allocative function of labour market, led to growing inequalities (Hoeven, 2000). The market driven forces and institutional changes are associated as the reasons of the rising inequalities.

The role of labour market institutions is to improve equity and social justice among labour force participants. The rigid institutions affect inequalities through changes of labour market rules. From the point of view of workers these factors are: decrease in social protection, work security, decrease in the public employment, decrease of collective bargaining (Kumor, 2010). Although there is a relatively extensive literature examining the relations between inequalities and labour market institutions, the results are however ambiguous. As shown by some recent papers, there are the different — often opposing — approaches and conclusions in analysing these issues.

On one hand, rigid institutions are negatively correlated with the Gini coefficient. The impact of institutions occurs both through a compression of the wage differential and a higher labour share (Checchi \& Garcia-Penalosa, 2008). It is explained that the more rigid labour market institutions the lower the level of employment. The lower the unemployment, the lower the inequalities, because of unions demand higher wages or due to higher expected costs of labour faced by employers (Checchi \& Garcia-Penalosa, 2008). Moreover redistributive policies embedded in unemployment benefits decrease income inequalities. Labour market institutions (trade unions) decrease wage dispersion and may contribute to lower inequalities (Checchi \& Garcia-Penalosa, 2010).

On another hand, more flexible institutions connected with more competitive markets, affect higher unemployment rates and tend to increase overall inequality by affecting the number of individuals with low incomes (Acemoglu, 2003, pp. Fl21-Fl49). What is more, institutions can support for investment, increase productivity and improve the standard of living of the participants of labour market (Amadeo \& Pero, 2000, pp. 120-148). The same institutions of labour market can increase inequalities because they reduce the participation in the labour force and result in the increase the taxes needed to finance the unemployment benefits (Berg, 2015; Burniaux et al., 2006).

The majority of results concluded that the effect of labour market institutions on inequalities was negligible and depended on the age and a social group. Jaumotte and Buitron (2015) focused on union density and the minimum wage as the evidence of the effects of the labour market institutions was not robust. The similar results of tax wedges and union density rate on inequalities are in general not significant are presented by Checchi and Garcia-Penalosa (2010). Although the study of relationships between income inequalities and labour market institutions encounters difficulties arising from the problems in measuring labour market institutions themselves (multidimensionality of the phenomenon, changes in time, due to individual characteristics of individuals may cause different reactions of individuals on the labour market, family composition), there 
are such studies in the literature (Alderson \& Nielsen, 2002, pp. 1244-1299; Rueda \& Pontussom, 2000; Wallerstein, 1999). However, special attention is paid to the analysis of relationships between measures of particular labour market institutions and income inequalities. The results are not satisfactory from the point of view of statistical requirements for most of the analyzed variables. Therefore, this article attempts to build a synthetic measure of labour market institutions, create a ranking of countries and look for relationships between labour market regulations and income inequalities in a more holistic perspective.

\section{Methods}

Labour market institutions are treated as a multi-dimensional space which is characterised by set of the potential diagnostic variables. In our paper we consider the effect of measures of labour market institutions, namely: hiring and firing regulations, hiring regulations and minimum wage, centralized collective bargaining, hours regulations, mandated costs of dismissal.

The set of the potential diagnostic variables is dependent on merits of the phenomenon of inequality and availability of data in 2010 and 2016 for all selected countries. 28 European Union countries were included to the analysis and considered as the objects. All the data were obtained from Fraser Institute.

Other authors consider also labour market institutions, namely union density, union coverage, centralisation of wage bargaining, coordination of wage bargaining, minimum wage, unemployment benefit, employment protection legislation, tax wedge, active labour market policies (Checchi \& Garcia-Penalosa, 2008; Eichhorst et. al., 2008; Holmlund, 2014; Pilc, 2015).

Diagnostic set of data was characterized by low level of similarity and low correlation among each other (Zeliaś, 2000). All potential diagnostic variables fulfilled mentioned conditions (variability coefficient which exceed the threshold value of $10 \%$, the Pearson correlation coefficient not more than 0.8 ) and were treated as set of final diagnostic variables.

In the next step, the normalization of final diagnostic variables by using standard deviation was applied (Kolenda, 2006; Zeliaś, 2000). The synthetic measure of diagnostic variables was achieved by calculation of mean of final diagnostic variables for every object (Zeliaś, 2000).

To measure the dependence between the synthetic measure of institutions and inequality the Pearson's correlation coefficient was applied and additionally the Spearman's rank correlation coefficient. Different measures of inequalities were used: Gini coefficient, s80/s20 income quintile share ratio. We also took into consideration relation between the synthetic measure of labour market institutions and in-work at risk of poverty rate 18-64 and cases of part-time work and full-time work (data source EU SILC, Eurostat).

Additionally, the objects were grouped. In order to group objects by measures of labour market institutions the Ward's Method was used. The Ward method is intended for intervalscaled measurements and makes use of Euclid- 
ean distances (Kaufman \& Rousseeuw, 2005). Excel and R system was used for statistical computation and graphics.

\section{Results}

The ranking of countries was done on the basis of synthetic measure of institutional variables. Austria, Germany, Greece, Belgium were the countries that belong to the group characterized by the most rigid labour market institutions in 2010 and 2016. Labour market regulations were the most flexible in Bulgaria, Cyprus, Denmark and Latvia, UK in both years. There were significant changes within countries regarding to labour market institutions between 2010 and 2016 in some countries, however. The most spectacular changes occurred in: Romania, Luxembourg, Netherlands, Croatia, Slovak Republic, Finland (table 1).

Romania, one of the poorest nations in Europe, faced critical challenges in its efforts to implement labour market and social programs similar to those found in more developed countries. Massive emigration after 2014 caused the troubles in finding workers. Therefore many activities were undertaken to make the institutions more elastic. The example of setting new, more flexible rules are: the possibility of dismissal of trade union leaders, the new occasional activities can be performed by day labourers, the employees shall have the right to benefit of the annual rest leave even if the temporary work incapacity lasts for the entire calendar year. As a result, the position in the ranking decreased drastically between 2010 and 2016 .

The position of Luxembourg also deteriorated in the ranking in regarding to labour market institutions. This country is amongst the top performers in terms of low labour market insecurity and very high earnings quality. Activities undertaken to make the labour market regulations more elastic were also addressed to overcome the challenges Luxembourg faces as a result of population ageing (OECD, 2017).

Many reforms in reducing the rigidity of labour market were introduced in the Netherlands. Employment protection was reformed to enhance the fairness and efficiency of dismissal procedures. Reforms aimed to result in better access to open-ended contracts. The dramatic drop in the ranking of labour market institutions is the visible result of these changes (OECD, 2016).

The implementation of the Labour Act reform in Croatia in 2014 was observed in substantial changes within labour market rules. In turn, the consequences were observed in the ranking of Croatia (table 1). The country from the end of the ranking was promoted to the fourth position, which means that labour market become more rigid. Main differences were noticed in hiring and firing regulations as well as minimum wage (European Commission, 2017; Fraser Institute Database, 2018).

Also huge difference between 2010 and 2016 in the ranking was noticed in Slovakia. In Slovakia during six years were observed mainly changes in hiring 
regulations and minimum wage mainly due to withdrew of a number of liberalised changes in 2012 (Piasna \& Myant, 2017).

Finland is characterised by a largely centralised wage bargaining system. The big change in the ranking of Finland was noticed due to the modification in centralized collective bargaining. In 2016, the centralized collective bargaining was estimated on the level of 2 (in 2010 almost 4) on the scale 1-7, where 7 means that wages are set by an individual company. The mentioned changes had consequences to the more rigid image of synthetic measure of labour market institutions.

In the next step of the analysis, countries were divided into 6 groups by the Ward's method. The results of grouping in 2010 were different from those in 2016 (chart 1, chart 2). In 2010, in Romania the situation was characterized by very rigid institutions that protected the workers to the high extent. Because both in the aspect of hiring and firing regulations and mandated costs of dismissal the regulations were significantly more rigid than in other countries. Romania was the only country in the group. The next group consisted of Estonia, France and Luxembourg and was characterized by very rigid institutions in the aspect of hours regulations. Similar, relatively rigid hiring and firing regulations were common to the group of 4 other countries (Greece, Poland, Spain, Sweden). Austria, Finland, Italy, Belgium, Netherlands and Germany were similar in highest elasticity of mandated costs of dismissal regulations. Croatia, Latvia and Slovak Republic were similar in according to relatively elastic hours regulations. The characteristic feature of the rest of the countries (Denmark, Ireland, UK, Bulgaria, Cyprus, Hungary, Malta, Lithuania, Portugal, Czech Republic, Slovenia) in 2010 were relatively elastic hours regulations and collective bargaining (chart 1).

In 2016, because of the changes in different labour market institutions within the European Union the groups of the countries were different. The group of Denmark, UK, Germany, Ireland, Lithuania, Czech Republic and Poland was characterized by hiring regulations and minimum wage rigid regulations. The group of: Latvia, Netherland, Romania, Cyprus, Malta was characterized by flexible hours regulations. Estonia, Belgium, Sweden, Bulgaria, Hungary were similar in relatively flexible hours regulations and mandated costs of dismissal. Austria and Finland were similar in very rigid and much stronger regulations in regarding to centralized collective bargaining. Greece and Spain characteristic features were very rigid and much stronger than in other countries regulations of mandated costs of dismissal. In the last group of Slovenia, Italy, Croatia, Slovak Republic, France, Luxembourg, Portugal the most similar were mandated costs of dismissal which were relatively elastic (chart 2).

For the countries grouped in 2010 and 2016 average Gini was calculated. The results are ambiguous. In 2010, Romania characterized as a very rigid country achieved the Gini index at the level of 33.5. In turn, for the group of countries with very rigid institutions in the aspect of hours regulations (Estonia, France and Luxembourg) the average Gini index amounted to the lowest average level 
(29.6) in all 6 groups of countries. Surprisingly, the highest level of average Gini index (34.8) in 2010 appeared in group of countries with relatively flexible hours regulations and collective bargaining (group of countries with Denmark, see chart 1). The average Gini index for Croatia, Latvia and Slovak Republic amounted to 31.1 in 2010. Almost similar level (31.5) was noticed for the group consisted of Austria, Finland, Italy, Germany, Belgium and Netherland.

In 2016, for two most characteristic groups: Austria and Finland (characterized by very rigid institutions: centralized collective bargaining) and Greece and Spain (also very rigid institutions: mandated costs of dismissal) the average Gini indices were completely opposite. It was respectively 26.3 and 34.4. When in the other groups the Gini index was between 29.4 and 31.3, e.g. in the group characterized by relatively elastic institutions inequalities are relatively low (Gini=29.4). The results of this comparison show there was no direct relationship between labour market institutions and inequalities in 2010 as well as in 2016.

The results of the analysis of the relationships between labour market institutions and inequalities measured by Gini index and s80/s20 income quintile share ratio showed that there was very weak or was no relations both in 2010 (respectively $-0.01,-0.01$ ) and 2016 (respectively $-0.24,-0.19$ ) (table 2). In 2010, weak positive relation (0.50) between labour market institutions and inwork at-risk-of-poverty rate among people at the age 18-64 was noticed. Almost the same level of correlation was observed in 2010 between labour market institutions and in-work at-risk-of-poverty rate by full-time work (0.48). Weaker relation occurred in case of part-time work (table 2). What is more in 2016, there was also a weak relation between labour market institutions and in-work at-risk-of-poverty rate among people at the age 18-64 and was higher relation in the group in-work at-risk-of-poverty rate by part-time work (-0.29). Signs of all correlation coefficients were negative in 2016. In 2016, the more rigid the institutions of labour market the lower the inequalities. But the results can't prove the strong relation. Furthermore the results of the Pearson's correlation coefficient and the Spearman's rank correlation coefficient were comparable.

\section{Conclusion}

The explanations of the relationships between labour market institutions and income inequalities should be multicriterial, because varying combination of institutions (inclusive as well as extractive) create the circumstances on the labour market. In the article only selected written rules defining employment relations were included. More institutions also informal like social consensus may contribute to lower inequalities. Another important aspect is, as emphasised R. Osterkamp (2016), different rules included into labour market institutions are complex and country-specific. Those for example both highly decentralized and of highly centralized wage settings can produce socially efficient results. Therefore in the article is no consensus between group of countries and average 
Gini index as well as different directions of relations. As the result of the analysis the weak correlation between the synthetic measure of institutions and inequality was identified.

The conducted study, however, allows for the conclusion that labour market institutions changed in the analysed period. In general the rules shaping the labour market conditions became more elastic in 2016 than in the 2010. The small increase in the income inequalities was observed in these years. But detailed analysis shown very differentiated changes both in the aspect of increasing or decreasing labour market rules rigidity as well as regarding to income inequalities.

The finding of the study, hence, raise the question of identification of the more factors which could have influence on the relationships between income inequalities and labour market institutions in regarding to each country separately. Therefore the authors are going to conduct the in-depth analysis in this perspective in the future.

\section{References}

Acemoglu, D. (2003). Cross-country inequality. The Economic Journal, 113(485). doi:10.1111/1468-0297.00100.

Acemoglu, D., \& Robinson, J. (2013). Economics versus politics: pitfalls of policy advice. Journal of Economic Perspectives, 27(2). doi:10.1257/jep.27.2.173.

Acemoglu, D., \& Robinson, J.A. (2012). Why nations fail: the origins of power, prosperity, and poverty. New York: Crown Publishers.

Alderson, A.S., \& Nielsen, F. (2002). Globalisation and the great U-turn: income inequality trends in 16 OECD countries. American Journal of Sociology, 107(5). doi:10.1086/341329.

Amadeo, E.J., \& Pero, V. (2000). Adjustment, stabilisation and the structure of employment in Brazil. Journal of Development Studies, 36(4). doi:10.1080/00220380008422640.

Berg, J. (2015). Labour market institutions: the building blocks of just societies. In J. Berg (Ed.), Labour markets, institutions and inequality: building just societies in the 21st century. Cheltenham-Northampton: Edward Elgar Publishing. doi:10.4337/9781784712105.00007.

Berg, J., \& Kucera, D. (2008). In defence of labour market institutions: cultivating justice in the developing world. New York: Palgrave Macmillan. doi:10.1057/9780230584204.

Burniaux, J., Padrini, F., \& Brandt, N. (2006). Labour market performance, income inequality and poverty in OECD countries. OECD Economics Department Working Papers, 500. doi:10.1787/882154447387.

Checchi,D., \& Garcia-Penalosa,C. (2008). Labourmarketinstitutionsandincome inequality. Economic Policy, 23(56). doi:10.1111/j.1468-0327.2008.00209.x. 
Checchi, D., \& Garcia-Penalosa, C. (2010). Labour market institutions and the personal distribution of income in OECD Counries. Economica, 77(307). doi:10.1111/j.1468-0335.2009.00776.x.

Eichhorst, W., Feil, M., \& Braun, C. (2008). What have we learned? Assessing labor market institutions and indicators. IZA Discussion Paper, 3470.

European Commission. (2010). Europe 2020: a strategy for smart, sustainable and inclusive growth. $\operatorname{COM(2010)} 2020$ final.

European Commission. (2017). Labour market policy thematic review 2017: an in-depth analysis of the impact of reforms on inequality: Croatia. Retrieved 01.06.2018 from https://ec.europa.eu.

Fraser Institute Database. (2018). Retrieved 01.06.2018 from https://www. fraserinstitute.org.

Hoeven, R. (2000). Labor markets and income inequality what are the new insights after the Washington consensus? UNU/WIDER Working Papers, 209.

Holmlund, B. (2014). What do labor market institution do? Labour Economics, 30. doi:10.1016/j.labeco.2014.06.007.

Jaumotte, F., \& Buitron, C. (2015). Inequality and labor market institutions, IMF Staff Discussion Notes, 15(14). doi:10.5089/9781513577258.006.

Kaufman, L., \& Rousseeuw, P.J. (2005). Finding groups in data: an introduction to cluster analysis. Hoboken: Wiley.

Kolenda, M. (2006). Taksonomia numeryczna: klasyfikacja, porządkowanie i analiza obiektów wielocechowych. Wrocław: AE we Wrocławiu.

Kumor, P. (2010). Zależność nierówności płac od poziomu rozwoju gospodarczego. Gospodarka Narodowa, 241(7-8). doi:10.33119/gn/101156.

North, D.C. (1990). Institutions, institutional change and economic performance, political economy of institutions and decisions. Cambridge: Cambridge University Press. doi:10.1017/CBO9780511808678.

North, D.C. (1993). Institutions, transaction costs and productivity in the long run. Economic History, 9309004.

North, D.C. (2002). Understanding economic change and economic growth. Warsaw: Leon Koźmiński Academy of Entrepreneurship and Management.

OECD. (2016). OECD employment outlook. doi:10.1787/empl_outlook-2016-en.

OECD. (2017). OECD employment uutlook. doi:10.1787/empl_outlook-2017-en.

Osterkamp, R. (2016). International experiences on labor market reforms. CESifo Forum, 17(1).

Piasna, A., \& Myant, M. (Eds.). (2017). Myths of employment deregulation: how it neither creates jobs nor reduces labour market segmentation. Brussels: Etui.

Pilc, M. (2015). Determinants of the labour market institutions in post-socialist economies. Communist and Post-Communist Studies, 48(2-3). doi:10.1016/j. postcomstud.2015.06.008.

Rueda, D., \& Pontusson, J. (2000). Wage inequality and varieties of capitalism. World Politics, 52(3). doi:10.1017/s0043887100016579.

Scott, W.R. (2014). Institutions and organizations: ideas, interests, and identities. Thousand Oaks: SAGE Publications. 
United Nations. (2015). Transforming our world: the 2030 agenda for sustainable development. New York: UN Publishing.

Wallerstein, M. (1999). Wage setting institutions and pay inequality in advanced industrial societies. American Journal of Political Science, 43(3). doi:10.2307/2991830.

Zeliaś, A. (Ed.). (2000). Taksonomiczna analiza przestrzennego zróżnicowania poziomu życia w Polsce w ujęciu dynamicznym. Kraków: AE w Krakowie.

\section{Acknowledgements}

Author contributions: authors have given an approval to the final version of the article. Authors contributed to this work equally.

Funding: this research was funded by the authors' own sources.

Note: the results of this study were presented at Second Scientific Conference Institutions: theory and practice (June, 19-20 2018, Torun, Poland). 


\section{Appendix}

Table 1.

Ranking of European Union countries in 2010 and 2016

\begin{tabular}{|c|c|c|c|c|c|c|}
\hline Country & $\begin{array}{c}\text { Institutions } \\
\text { ranking } 2010\end{array}$ & $\begin{array}{c}\text { Institutions } \\
\text { ranking } 2016\end{array}$ & $\begin{array}{c}\text { Change (places) } \\
2016 / 2010\end{array}$ & $\begin{array}{l}\text { Gini ranking } \\
2010\end{array}$ & $\begin{array}{l}\text { Gini ranking } \\
2016\end{array}$ & $\begin{array}{c}\text { Change (places) } \\
2016 / 2010\end{array}$ \\
\hline Austria & 4 & 1 & -3 & 18 & 22 & -4 \\
\hline Belgium & 7 & 6 & -1 & 21 & 24 & -3 \\
\hline Bulgaria & 25 & 21 & -4 & 6 & 1 & 5 \\
\hline Croatia & 26 & 4 & -22 & 10 & 13 & -3 \\
\hline Cyprus & 24 & 27 & 3 & 14 & 10 & 4 \\
\hline Czech Republic & 19 & 18 & -1 & 26 & 26 & 0 \\
\hline Denmark & 20 & 22 & 2 & 20 & 20 & 0 \\
\hline Estonia & 18 & 13 & -5 & 11 & 9 & 2 \\
\hline Finland & 21 & 8 & -13 & 25 & 25 & 0 \\
\hline France & 10 & 3 & -7 & 15 & 17 & -2 \\
\hline Germany & 5 & 5 & 0 & 16 & 15 & 1 \\
\hline Greece & 3 & 2 & -1 & 7 & 6 & 1 \\
\hline Hungary & 17 & 16 & -1 & 27 & 19 & -8 \\
\hline Ireland & 14 & 19 & 5 & 13 & 15 & -2 \\
\hline Italy & 11 & 14 & 3 & 9 & 8 & -1 \\
\hline Latvia & 28 & 26 & -2 & 2 & 4 & -2 \\
\hline Lithuania & 12 & 9 & -3 & 1 & 2 & -1 \\
\hline Luxembourg & 13 & 25 & 12 & 19 & 12 & 7 \\
\hline Malta & 16 & 24 & 8 & 17 & 18 & -1 \\
\hline Netherlands & 9 & 20 & 11 & 23 & 23 & 0 \\
\hline Poland & 6 & 15 & 9 & 12 & 13 & -1 \\
\hline Portugal & 23 & 17 & -6 & 3 & 7 & -4 \\
\hline Romania & 1 & 28 & 27 & 4 & 3 & 1 \\
\hline Slovak Republic & 27 & 12 & -15 & 22 & 28 & -6 \\
\hline Slovenia & 15 & 11 & -4 & 28 & 27 & 1 \\
\hline Spain & 8 & 7 & -1 & 4 & 4 & 0 \\
\hline Sweden & 2 & 10 & 8 & 23 & 21 & 2 \\
\hline UK & 22 & 23 & 1 & 7 & 11 & -4 \\
\hline
\end{tabular}

Notes:

Countries were grouped based on synthetic measure of institutional variables.

Source: Own calculations. 
Table 2.

The Pearson's Correlation Coefficient between labour market institutions and inequalities in 2010 and 2016

\begin{tabular}{lccccc}
\hline $\begin{array}{c}\text { Synthetic labour } \\
\text { market institutions } \\
\text { measure }\end{array}$ & Gini & S80/S20 & $\begin{array}{c}\text { In-work at-risk-of- } \\
\text { poverty rate 18-64 }\end{array}$ & $\begin{array}{c}\text { In-work at-risk- } \\
\text { of-poverty rate by } \\
\text { part-time work }\end{array}$ & $\begin{array}{c}\text { In-work at-risk- } \\
\text { of-poverty rate by } \\
\text { full-time work }\end{array}$ \\
\hline 2010 & -0.01 & -0.01 & 0.50 & 0.26 & 0.48 \\
2016 & -0.24 & -0.19 & -0.15 & -0.29 & -0.11 \\
\hline
\end{tabular}

Source: Own preparation.

Chart 1.

Dendrogram of European Union countries in 2010

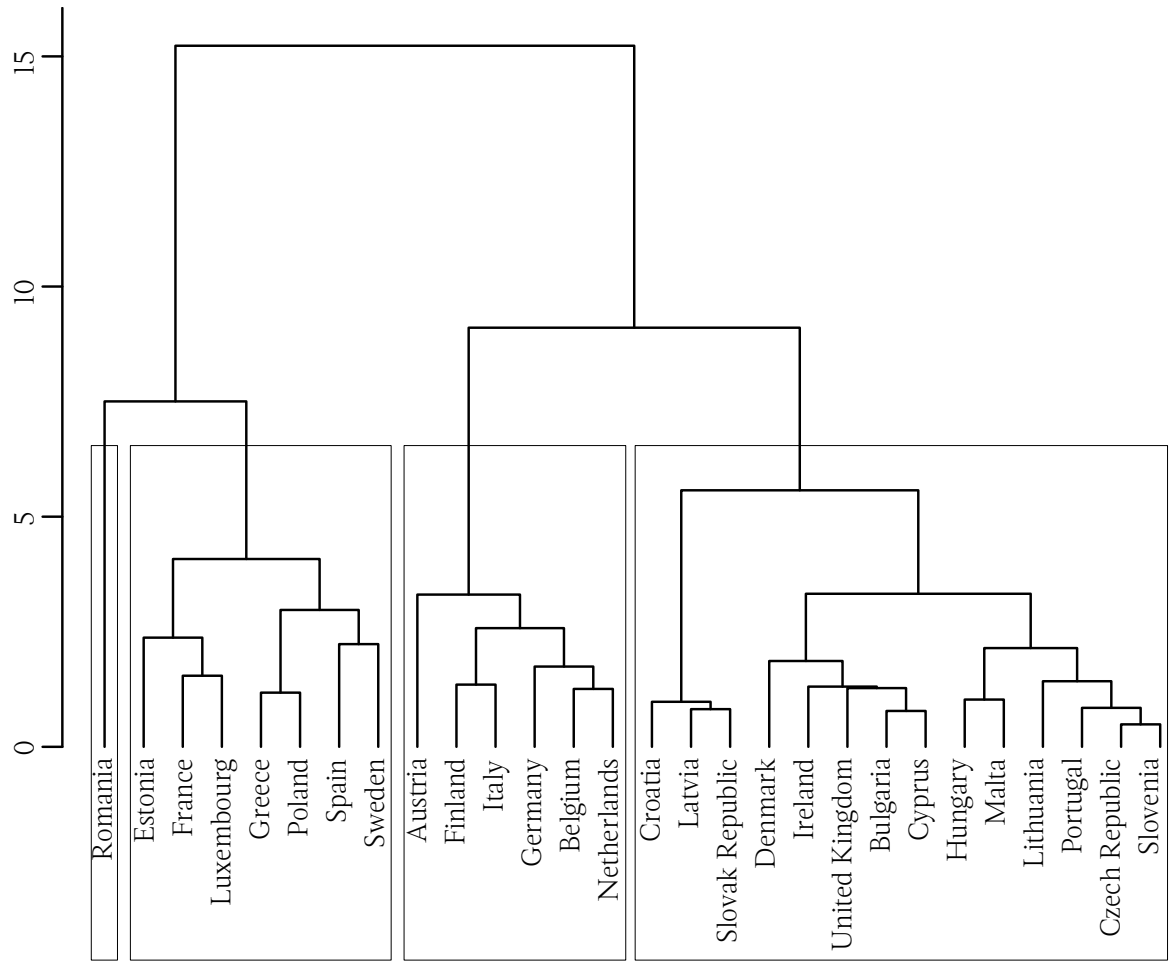

Source: Own preparation. 
Chart 2.

Dendrogram of European Union countries in 2016

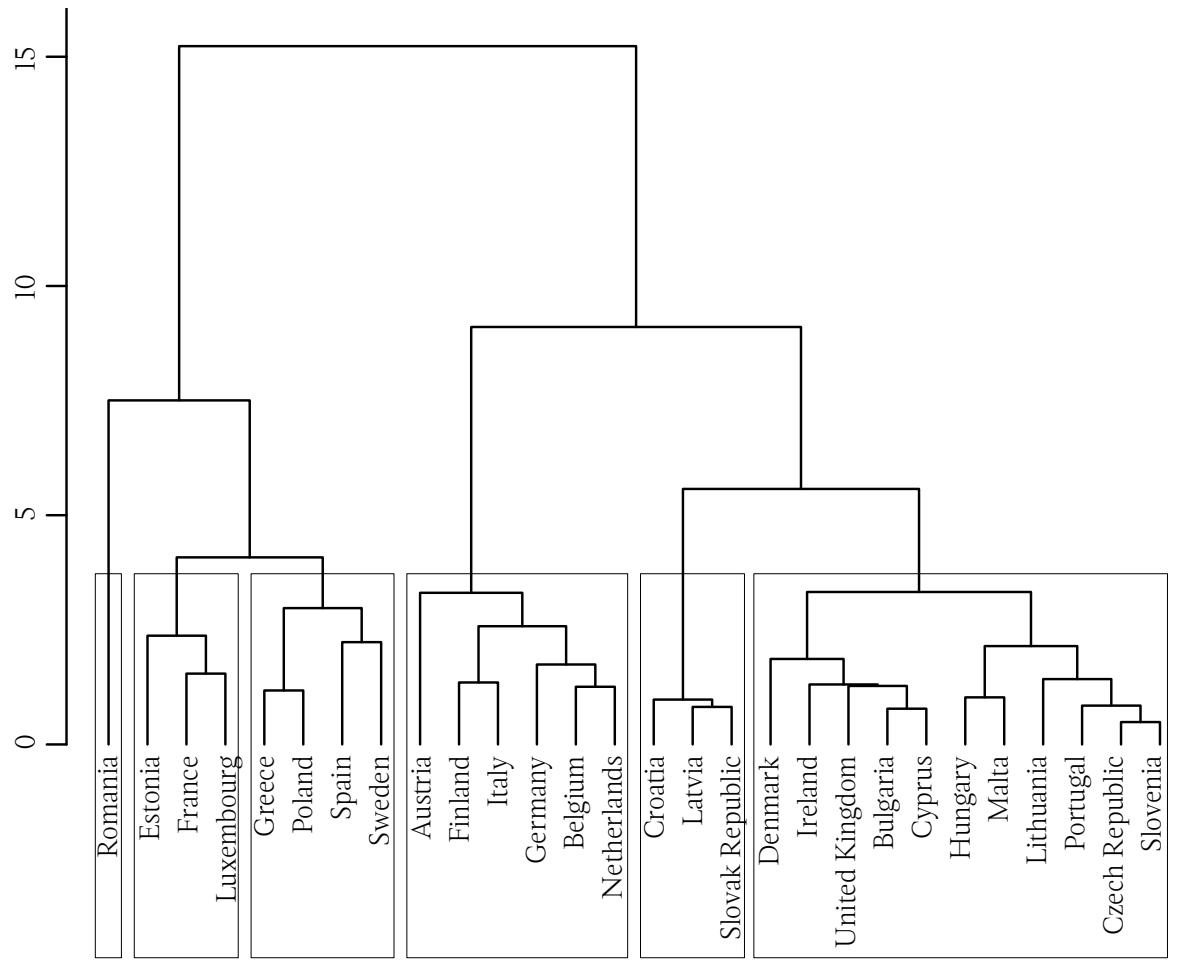

Source: Own preparation. 
